\title{
Tedung Bali Craft Business Development: SWOT Analysis and Marketing Strategy
}

\author{
Nyoman Dwika Ayu Amrita1 ${ }^{*}$, Made Mulia Handayani² \\ 1,2 Faculty of Economics and Business, Ngurah Rai University, Bali, Indonesia
}

\section{A R T I C L E I N F O}

Article history:

Received 18 August 2020

Received in revised form

5 September 2020

Accepted 18 December

2020

Available online 01

February 2021

Keywords:

SWOT, Marketing Strategy

\begin{abstract}
A B S T R A C T
The local potential of the cultural heritage must be able to improve the village economy and the welfare of micro business craftsmen. Tedung is one of the medium of Hinduism ceremony. There is quite a tight competition in Tedung marketing. Marketing is difficult because people don't buy Tedung every day. The types of Tedung handicraft products produced by craftsmen in Mengwi village are still limited with several designs, even though according to their needs and functions. Strategic planning for business development needs to be made so that the operations of Tedung craftsmen can run effectively and efficiently. This study aims to formulate a business development strategy and make Tedung, the handicraft business of the Tedung as an economic booster for the community. This study uses descriptive qualitative research methods with SWOT analysis. This method is able to analyze strengths, weaknesses, opportunities and threats. The data were obtained from interviews with business owners and consumers. The research stages consisted of literature studies, field studies, problem formulation, conducting data analysis using SWOT, formulating marketing strategies for business development for Tedung craftsmen. The target output is that the craftsmen have the knowledge to develop business with increasing efficiency, productivity, scale of production and business competitiveness to get a better welfare.
\end{abstract}

Copyright (C) Universitas Pendidikan Ganesha. All rights reserved.

\section{Introduction}

The industrial sector plays a strategic role in achieving economic development goals. The industrial sector also has a big role in driving economic growth (Desiyanti, 2016). In developing countries, industries classified as small and medium enterprises (UKM) are a major source of national income and create an important area for entrepreneurship. This UKM also has a big role in terms of increasing employment. The importance of the UKM sector has been recognized worldwide for its significant contribution in satisfying various socio-economic goals such as higher employment growth, output and exports(Hidayet, 2010). In the developing countries, such as Indonesia, $86 \%$ of new jobs are created by small and medium business. Both in developed and developing countries, cultures and creativities play risk, structural policy, are the foundation for growth and prosperity entrepreneurship activities (Sudrajat et al., 2016).

Small and medium enterprises play an important role in economic growth and stability in Indonesia. UKM face many challenges affecting their growth and existence. However, it is rare to face strategic management planning such as a SWOT analysis that considers the external environment for opportunities and threats as well as internal conditions for strengths and weaknesses (Thamrin et al., 2017). The SWOT analysis also shows that farmer groups in the MTP Cooperative can advance by utilizing the ST strategy because it has the highest score when compared to others, which is 8.668 (Hadi et al., 2017). To minimize weaknesses, a more accurate and comprehensive performance measurement system is needed that can provide alternative strategies for companies such as the implementation integration of SWOT (Setiawannie \& Rahmania, 2019). 
The industrial sector, especially a small and household industries in Bali area, is growing rapidly in line with the rapid development of the tourism industry. This opens up employment and business opportunities for people in Bali. Bali is rich in cultural heritage that can attract foreign tourists. The local potential of this cultural heritage is expected to be able to stimulate the village economy and improve the welfare of micro business craftsmen (Badung, 2018). Mengwi Village is known as a village with a producer of Balinese handicrafts / umbrellas. Tedung is a complement to the ceremony which is shaped like an umbrella and used in Yadnya ceremonial specifically in Bali (Sudiatmika et al., 2017). Various Balinese handicrafts from Mengwi village are marketed throughout Bali, including tourist destinations, which are sold not only for customary purposes and religious rituals but also for tourism needs, household and office decorations (Kusumawijaya, 2017).

The Tedung handicraft industry is one of the sources of income for the people in Mengwi village. This Tedung craft has a role in creating jobs for the community. Tedung craft business is a hereditary business. However, in the midst of efforts to continue to exist, most of the Tedung handicraft industries found it difficult to develop due to several obstacles. Based on the results of observations with the Tedung craftsmen in Mengwi village, there are several problems faced by the craftsmen include low working capital, unorganized recording of financial reports, limited distribution channels, and price competition in the market, considering that almost all districts in Bali have Tedung craftsmen. Marketing is difficult because people don't buy Tedung every day. The types of Tedung handicraft products produced by craftsmen in Mengwi village are still limited to Tedung with several designs, even though currently according to their needs and functions, Tedung handicraft products are in great demand by the community with a variety of designs (Kusumawijaya, 2017). Innovation affects organizational performance positively through the marketing strategy process. In particular, it is explained that marketing mediates the relationship between innovation and organizational performance. So that the innovation of Tedung production design is very important in order to achieve higher performance. There should be craftsmen's efforts to determine business strategies, especially competitive strategies. Competitive strategy is defined as a strategy that is implemented by craftsmen to find a profitable and sustainable position in their industry (Finoti et al., 2017; Nourlette \& Hati, 2017).

SWOT analysis can be classified into: strength (strength) is a resource of skills or advantages relative to competitors and the market needs of a company that can be served or want to be served. Strength relates to financial resources, image, market leadership, buyer relationships and other factors. Weaknesses (weaknesses) are limitations or deficiencies in resources, skills and abilities that seriously hinder the effective performance of a company. Opportunities (opportunities) are a major advantageous situation in a corporate environment. Threats (threats) are the main unfavorable situation in the environment of a company which is a major obstacle to the company's position. The entry of new competitors, slow market growth, bargaining power of buyers, changes in technology and new regulations can be a threat to the company (Sukaatmadja et al., 2015).

Based on this classification, it can be explained that the SWOT analysis is an analysis that can be used to formulate a strategy which consists of an analysis of the advantages, disadvantages, opportunities and threats faced by a company to achieve its goals (Sukaatmadja et al., 2015). SWOT analysis is also used in research conducted by (Desiyanti, 2016; Finoti et al., 2017; Hidayet, 2010; Mondal, 2017; Thamrin et al., 2017). The preparation of strategic planning is carried out in three stages: (1) the data collection stage, at this stage the activities carried out are data collection, data classification and data pre-analysis which are used in two types, namely external and internal data, (2) analysis stage, in this stage quantitative models of strategy formulation are used, after collecting all the information that affects the company's sustainability. The next stage uses all the information obtained into quantitative models of strategy formulation. In this study, an internal-external matrix will be used (Sukaatmadja et al., 2015)

Marketing is done to meet needs where these activities are carried out in a profitable way (Kotler \& Keller, 2016). Marketing is an organizational function and a set of processes for creating, communicating and conveying value to consumers and to develop consumer relationships that provide benefits to the organization and the parties with an interest in the organization (Puriansa \& Donni, 2017). The American Marketing Association (AMA) defines marketing as an activity, a series of institutions and processes to create, communicate, deliver and offers exchange of the value to customers, clients, partners and the wider community (Kotler \& Keller, 2016). Marketing strategy is a market-driven process of developing a strategy that takes into account the changing environment and the need to offer superior customer value. In this case, the marketing strategy connects the organization with the environment and views marketing as a function that has more responsibility than other functions in overall business activities (Puriansa \& Donni, 2017).

The marketing strategy prioritizes customer orientation by providing the highest satisfaction and focusing on the appearance of institutions that prioritize increasing sales volume. With planning that is 
carried out actively and well, it will be able to anticipate future developments, even factors outside of the business environment can be controlled or predicted first (Alma, 2016; David, 2009; Mondal, 2017).

This study aims to analyze strategic factors including internal strengths and weaknesses as well as external opportunities and threats and is followed by the development of strategic planning based on the SWOT (Strength Weakness Opportunity Threat) matrix in order to create competitive advantages that can increase the welfare of craftsmen in particular and society. SWOT analysis is a matching tool that can help managers develop four types of strategies, namely the SO strategy (strength-opportunity), WO strategy (weakness-opportunity), ST strategy (strength-threat) and WT strategy (weakness-threat).

\section{Methods}

The research is located in the village of Mengwi, Bali. A qualitative approach that allows a researcher to interpret and explain phenomena holistically using words, without having to rely on numbers (Moleong, 2013). The tendency of qualitative research is more descriptive and emphasizes the completion process (Kurniawan \& Haryati, 2017). The object studied was the implementation of SWOT analysis and marketing strategies in the development of Tedung handicraft businesses in Mengwi village.It is the unit under study which can be in the form of an individual, group, object or an event setting as the research subject. In this study, the Tedung craftsmen. The data source used is primary data and secondary data. Primary data is data that is directly obtained from interviews with informants. The informants in this study were the Tedung craftsmen and consumers who bought Tedung. Secondary data, namely data obtained from documents and written materials, literature and publication materials. The technique of selecting informants is purposive (deliberate) technique. According to Singarimbun and Sofyan Effendi, it is not random, in which research subjects are selected based on certain considerations. Based on prarisets, the informants in this study were five Tedung craftsmen who had started a business for 20 years in Mengwi village (Singarmbun \& Effendi, 2008). The research stages are: (a) Study of literature; (b) Carry out data collection; (c) Formulation of the problem; (d) SWOT analysis; (e) Formulating a marketing strategy to increase the income of Tedung business artisans; (f) Draw conclusions.

Data Collection Methods is a systematic and very important way with the aim of solving the main problem in a study. The method of data collection in this research is done by: (1) Library Research by reads literature, reference materials, lecture materials and other research results that have something to do with the object under study; (2) Field Research by conducted direct observations on the condition of Tedung craftsmen and direct interviews with parties related to Tedung crafts (interview). The techniques for collecting data in this study is through by observation, documentation, and structured interview. The data analysis techniques in this study using Likert scale and SWOT matrix. Likert scale has the following stages: (a) Make closed questions that have the highest to lowest intensity answer scale. (b) Perform randomization of the order of questions. (c) Give weight to the answer choices. Value 5 is given the highest intensity and value 1 is the lowest intensity. (d) Recapitulate the weight of each question in the questionnaire given by the respondent. (e) Determine critical success factors from each of total weight which are the main factors that have an important impact on the success and failure of a business. (f) Determine the average weight for each critical success factor.

SWOT analysis is carried out through a series of calculations known as IFAS and EFAS calculations by taking into account the weight and rating values (Zainuri et al., 2019). The SWOT matrix consists of four types of business development strategies: (a) SO strategies (strengths-opportunities) maximize the strengths that are owned to take advantage of opportunities. (b) WO (weaknesess-opportunities) strategy can improve weaknesses by maximizing opportunities. (c) ST (strength-threats) strategy uses the strengths owned to minimize the influence of threats. (d) WT (Weakness-Threats) strategy, namely defensive tactics to reduce the influence of weaknesses and avoid threats.

\section{Results and Discussions}

\section{SWOT Matrix Qualitative Approach}

In the SWOT matrix there are eight area squares. The top two boxes are external environmental factors that contain opportunities and challenges for Tedung craftsmen in Mengwi village. The two boxes on the left are internal environmental factors that contain the strengths and weaknesses of the craftsmen in Mengwi village. Meanwhile, the other four boxes are boxes containing strategic issues resulting from the meeting between internal and external environmental factors. 
Table 1. SWOT Matrix for Tedung Crafters

\begin{tabular}{|c|c|c|}
\hline Internal & Opportunities & Threats \\
\hline Strengths & Comparative Advantages & Mobilization \\
\hline Weaknesses & Divestment/Investment & Damage Control \\
\hline
\end{tabular}

SO (Strengths Opportunities) strategy of Tedung craftsmen is to maximize the strength of the internal environment to take advantage of opportunities in the external environment. The WO (Weaknesses Opportunities) strategy used by Tedung craftsmen is to improve the weaknesses of the internal environment by making the most of the opportunities for the external environment. The Tedung craftsman's ST (Strengths Threats) strategy was to use force to reduce the influence of external environmental threats. While the WT (Weakness Threats) strategy is to reduce the weakness of the internal environment and avoid threats that come from the external environment (Kurniawan \& Haryati, 2017).

\section{SWOT Matrix Quantitative Approach}

Environmental factor analysis data contained in the SWOT matrix for Tedung craftsmen can be converted into quantitative data through SWOT calculations. It is done to determine the exact position of the Tedung crafter. This SWOT calculation is carried out in three stages as follows: (1) Calculating the score, weight and total multiplication of the score with the weight for each environmental factor. (2) Reducing the total number of the strength factor (S) with the weakness factor $(\mathrm{W})$ and reducing the opportunity factor $(0)$ with the threat factor $(\mathrm{T})$. The obtained value for the difference between $\mathrm{S}$ and $\mathrm{T}$ will be the point on the $\mathrm{X}$ axis while the resulting difference between $\mathrm{O}$ and $\mathrm{T}$ will be the point on the $\mathrm{Y}$ axis. (3) Search for the position of the Tedung crafter in the SWOT quadrant based on the point ( $\mathrm{x}, \mathrm{y}$ ). The results of SWOT calculations for Tedung crafts are shown in table 2 and table 3.

Table 2. Calculation of SWOT Analysis of Internal Factors for Tedung Crafters

\begin{tabular}{|c|c|c|c|c|c|c|c|c|}
\hline No & Strength & $\begin{array}{c}\text { Weighted } \\
\text { Value }\end{array}$ & Scale & B $\times S$ & Weakness & $\begin{array}{l}\text { Weighted } \\
\text { Value }\end{array}$ & Scale & B $\times S$ \\
\hline 1 & $\begin{array}{l}\text { Good public } \\
\text { response to the } \\
\text { offered } \\
\text { products }\end{array}$ & 0,131 & 4 & 0,524 & $\begin{array}{l}\text { High cost of } \\
\text { goods }\end{array}$ & 0,09 & 3 & 0,27 \\
\hline 2. & $\begin{array}{l}\text { Long lasting } \\
\text { products }\end{array}$ & 0,105 & 4 & 0,42 & $\begin{array}{l}\text { The model is } \\
\text { not up to } \\
\text { date }\end{array}$ & 0,06 & 2 & 0,12 \\
\hline 3 & $\begin{array}{l}\text { Effect of } \\
\text { location on } \\
\text { good business } \\
\text { continuity }\end{array}$ & 0,08 & 4 & 0,32 & $\begin{array}{l}\text { Income } \\
\text { reduction } \\
\text { risk }\end{array}$ & 0,09 & 4 & 0,36 \\
\hline 4 & $\begin{array}{l}\text { Maximum } \\
\text { service to } \\
\text { consumers }\end{array}$ & 0,125 & 3 & 0,375 & $\begin{array}{l}\text { Lack of } \\
\text { market } \\
\text { knowledge }\end{array}$ & 0,08 & 2 & 0,16 \\
\hline \multirow[t]{2}{*}{5} & $\begin{array}{l}\text { Guarantee of } \\
\text { good product }\end{array}$ & 0,118 & 3 & 0,354 & $\begin{array}{l}\text { Limited } \\
\text { asset }\end{array}$ & 0,09 & 1 & 0,09 \\
\hline & & & & 1,993 & & & & 1 \\
\hline
\end{tabular}

Table 3. Calculation of SWOT Analysis of External Factors of Tedung Crafters

\begin{tabular}{llllccccc}
\hline No & Opportunity & $\begin{array}{c}\text { Weighted } \\
\text { Value }\end{array}$ & Scale & B x S & Threat & $\begin{array}{c}\text { Weighted } \\
\text { Value }\end{array}$ & Scale & B x S \\
\hline 1 & $\begin{array}{l}\text { Capability of } \\
\text { capturing good } \\
\text { market }\end{array}$ & 0,101 & 4 & 0,404 & $\begin{array}{l}\text { High level } \\
\text { of business } \\
\text { competition }\end{array}$ & 0,088 & 2 & 0,176 \\
2. & Jalinan & 0,120 & 3 & 0,36 & High & 0,056 & 4 & 0,224
\end{tabular}




\begin{tabular}{|c|c|c|c|c|c|c|c|c|}
\hline No & Opportunity & $\begin{array}{c}\text { Weighted } \\
\text { Value }\end{array}$ & Scale & B $\times S$ & Threat & $\begin{array}{c}\text { Weighted } \\
\text { Value }\end{array}$ & Scale & B $\times S$ \\
\hline & $\begin{array}{l}\text { kerjasama } \\
\text { perajin dengan } \\
\text { konsumen } \\
\text { yang baik }\end{array}$ & & & & $\begin{array}{l}\text { business } \\
\text { risk }\end{array}$ & & & \\
\hline 3 & $\begin{array}{l}\text { The image of a } \\
\text { good } \\
\text { craftsman in } \\
\text { the eyes of } \\
\text { consumers }\end{array}$ & 0,127 & 3 & 0,381 & $\begin{array}{l}\text { Limited } \\
\text { skilled } \\
\text { workforce }\end{array}$ & 0,089 & 3 & 0,267 \\
\hline 4 & $\begin{array}{l}\text { High } \\
\text { community } \\
\text { demand for } \\
\text { Tedung } \\
\text { products }\end{array}$ & 0,094 & 3 & 0,282 & $\begin{array}{l}\text { Tedung } \\
\text { prices in } \\
\text { other areas } \\
\text { are cheaper }\end{array}$ & 0,069 & 3 & 0,207 \\
\hline \multirow[t]{2}{*}{5} & $\begin{array}{l}\text { Online market } \\
\text { development } \\
\text { opportunities }\end{array}$ & 0,127 & 2 & 0,254 & $\begin{array}{l}\text { Limited } \\
\text { knowledge } \\
\text { of crafter } \\
\text { on online } \\
\text { sales }\end{array}$ & 0,127 & 3 & 0,381 \\
\hline & & & & 1,681 & & & & 1,255 \\
\hline
\end{tabular}

In the SWOT quantitative approach table for Tedung craftsmen, there is a calculation of the strengths posture and competitive posture. The Strengths posture shows the cumulative calculation results of the internal factor variable values of Tedung craftsmen with the formula: Strengths Posture $=\mathrm{S}-\mathrm{W}$

While competitive posture is the cumulative calculation result of the external factor variable value of Tedung craftsmen with the formula:

$$
\text { Competitive posture }=0-\mathrm{T}
$$

So that from the calculations above, a SWOT quadrant matrix can be made as shown in Figure 1.

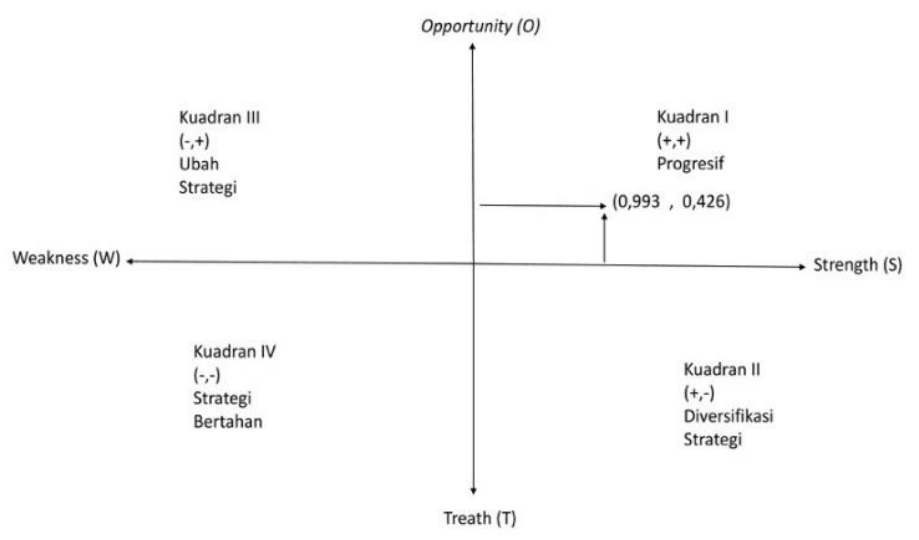

Figure 1. SWOT Quadrant Matrix for Tedung Crafters

From the internal and external analysis, the values 1.993 and 0.426 are located in quadrant I or in the position of growth-oriented strategy or in the SO strategy. The strength possessed by the Tedung craftsmen was greater than the existing weaknesses. Meanwhile, the opportunities for Tedung craftsmen were greater than the existing threats. This position indicates that the craftsmen in the village of Mengwi are strong and have opportunities. The results of this study are in line with the results of previous research conducted by (Desiyanti, 2016) which stated that the strengths of the Pitameh rattan entrepreneurs were greater than weaknesses and opportunities were greater than the existing threats. 
Then (Pantiyasa \& Rosalina, 2020) also stated that the position of Paksebali Village is in quadrant I where strength is greater than weakness and opportunities are greater than threats. The recommended strategy given was a progressive strategy, meaning that the position of the craftsmen was in prime and steady condition so that it was possible to continue to expand, increase growth and achieve maximum progress. The Tedung's product development strategy is at a profitable position. The good response of the community to the Tedung products and the guarantee of good product quality to consumers can increase market demand. Developing a more modern, innovative and creative Tedung model will be able to increase consumer interest and demand for Tedung crafts. Innovativeness and the marketing strategy process seem to be closely related. A strategic marketing decision-making process comprises strategic marketing decisions, process, methods and internal and external contextual factors (Finoti et al., 2017). A strategic location can be used to facilitate marketing. Likewise, the enthusiasm and discipline of work can develop this Tedung craft business (Desiyanti, 2016).

\section{Conclusion}

SWOT analysis is needed for Tedung craftsmen to find out what their strengths, weaknesses, opportunities and threats are. Based on the results of the SWOT analysis, the conditions of the craftsmen in Mengwi village are in the first quadrant, which is in a strong position and on the track. This craft business has greater strengths than weaknesses and the opportunities are greater than threats. Expanding, enlarging and accelerating business growth is a strategy that can be used by craftsmen in Mengwi village.

\section{References}

Alma, B. (2016). Manajemen Pemasaran dan Pemasaran Jasa. CV Alfabeta.

Badung, D. M. K. (2018). Industri Kerajinan Tedung/Payung Bali Sebagai Potensi Desa Mengwi.

David, F. . (2009). Manajemen Strategi. Salemba Empat.

Desiyanti, R. (2016). Analisis Swot dan Strategi Pengembangan Pada Keberhasilan Industri Kecil Rotan Kota Padang. Jurnal Apresiasi Ekonomi, 4(1), 1-14. https://doi.org/10.31846/jae.v4i1.142

Finoti, L., Didonet, S. R., Toaldo, A. M., \& Martins, T. S. (2017). The role of the marketing strategy process in the innovativeness-performance relationship of SMEs. Marketing Intelligence and Planning, 35(3), 298-315. https://doi.org/10.1108/MIP-01-2016-0005

Hadi, S., Wasahua, O., \& Masri, Z. A. (2017). Metode Analisis SWOT dalam Pelaksanaan One Village One Product Agribisnis Holtikultura (Studi Kasus di Koperasi Mitra Tani Parahyangan Cianjur). JABE (Journal of Applied Business and Economic), 4(2), 159. https://doi.org/10.30998/jabe.v4i2.2143

Hidayet, K. İ. (2010). The Importance of Small and Medium-Sized Enterprises (SMEs) in Economies: SWOT Analysis of The SME Sector in Turkey and Albania. Niğde Üniversitesi Íktisadi ve İdari Bilimler Fakültesi Dergisi, 3(1), https://dergipark.org.tr/en/pub/niguiibfd/issue/19746/211352

116-132.

Kotler, P., \& Keller, K. L. (2016). Marketing Management :15th Edition. Pearson.

Kurniawan, M., \& Haryati, N. (2017). Analysis of Business Development Strategy of Soursop Juice Beverage. Industria: Jurnal Teknologi Dan Manajemen Agroindustri, 6(2), 97-102. https://doi.org/10.21776/ub.industria.2017.006.02.6

Kusumawijaya, I. K. (2017). PKM Perajin Tedung Desa Mengwi Di Kabupaten Badung, Bali. Proceeding TEAM, 2, 897. https://doi.org/10.23887/team.vol2.2017.224

Moleong, L. J. (2013). Metodologi Penelitian Kualitatif Edisi Revisi (P. R. Rosdakarya (ed.)).

Mondal, S. H. (2017). SWOT Analysis and Strategies To Develop Sustainable Tourism in Bangladesh. UTMS Journal of Economics, 8(2), 159-167. https://www.econstor.eu/handle/10419/195304

Nourlette, R. R., \& Hati, S. W. (2017). Penentuan Strategi Dengan Pendekatan Analisis Swot Pada Hotel Nongsa Point Marina \& Resort Dalam Menghadapi Persaingan Bisnis. Inovbiz: Jurnal Inovasi Bisnis, 5(1), 82. https://doi.org/10.35314/inovbiz.v5i1.174

Pantiyasa, I. W., \& Rosalina, P. D. (2020). The Development Strategy of Paksebali Village Into Smart EcoVillage Destination as a Tourism Icon in Klungkung District-Bali. 226(Icss), 1469-1477. 
https://doi.org/10.2991/icss-18.2018.308

Puriansa, J., \& Donni. (2017). Perilaku Konsumen Dalam Persaingan Bisnis Kontemporer CV. Alfabeta

Setiawannie, Y., \& Rahmania, T. (2019). Performance measurement of public hospitals through the integration of SWOT and balanced scorecard. Jurnal Sistem Dan Manajemen Industri, 3(2), 76. https://doi.org/10.30656/jsmi.v3i2.1472

Singarmbun, M., \& Effendi, S. (2008). Metode Penelitian Survei (LP3ES (ed.)).

Sudiatmika, A. . I. A., Sadia, I. W., \& Supir, I. K. (2017). Komodifikasi tedung upacara menjadi lampu hias. 1,2. Seminar Nasional Pengabdian Kepada Masyarakat, 416-422. https://eproceeding.undiksha.ac.id/index.php/senadimas/article/download/1104/831

Sudrajat, J., Rahman, M. A., Sianturi, A., \& Vendy, V. (2016). Entrepreneurship Learning Process by using SWOT Analysis. The Winners, 17(1), 67. https://doi.org/10.21512/tw.v17i1.1811

Sukaatmadja, I. P. G., Yasa, N. N. K., Rahyuda, H., \& Widagda, I. G. N. J. (2014). Strategi Pengembangan Pasar Tradisional Berbasis Kearifan Lokal untuk Mengentaskan Kemiskinan di Bali. Matrik: Jurnal Manajemen, Strategi Bisnis dan Kewirausahaan, 8(2), 121-129. https://ocs.unud.ac.id/index.php/jmbk/article/view/14365

Thamrin, H., Herlambang, R., Brylian, B., Gumawang, A. K. A., \& Makmum, A. (2017). A SWOT analysis tool for Indonesian small and medium enterprise. ARPN Journal of Engineering and Applied Sciences, 12(2),

620-625. http://www.arpnjournals.org/jeas/research_papers/rp_2017/jeas_0117_5664.pdf

Zainuri, M., Nuringwahyu, S., \& Zunaida, D. (2019). Analisis SWOT Sebagai Dasar Untuk Merencanakan Strategi Pemasaran (Studi Pada Ciptaningati Culture Hotel). JIAGABI (Jurnal Ilmu Administrasi Niaga/Bisnis), 8(1), 40-50. http://www.riset.unisma.ac.id/index.php/jiagabi/article/view/1938 